\section{Redundancies and Genetic Structure among ex situ Apple Collections in Norway Examined with Microsatellite Markers}

\author{
Fuad Gasi and Kenan Kanlić \\ Faculty of Agriculture and Food Sciences, University of Sarajevo, Zmaja od \\ Bosne 8, 71000 Sarajevo, Bosnia and Herzegovina
}

Belma Kalamujić Stroil and Naris Pojskić Laboratory for Molecular Genetics of Natural Resources, Institute for Genetic Engineering and Biotechnology, University of Sarajevo, Zmaja od Bosne 8, Kampus, 71000 Sarajevo, Bosnia and Herzegovina

Åsmund Asdal, Morten Rasmussen, Clive Kaiser, and Mekjell Meland ${ }^{\mathbf{1}}$ Norwegian Institute of Bioeconomy Research, P.O. Box 115, N-1432 As, Norway

Additional index words. climate adaptation, ex situ collections, genetic diversity

\begin{abstract}
Apple genetic resources in Norway are currently conserved within a number of local clonal archives. However, during establishment of these ex situ collections, primary focus was not on capturing as much of the diversity as possible, but instead on preserving cultivars of particular importance to specific fruit-growing areas. To identify redundancies within the collection as well as to assess the genetic diversity and structure of apple germplasm currently being conserved in Norway, eight microsatellites were used in genetic characterization of 181 apple accessions. Overall, 14 cases of synonym or possibly mislabeled accessions were identified, as well as several homonyms and duplicates within and among the analyzed collections. The information obtained should contribute to overall better management of the preserved germplasm. Bayesian analysis of genetic structure revealed two major clusters, one containing most of the foreign cultivars, while the other consisted mainly of traditional Scandinavian cultivars, but also some very winter-hardy genotypes such as 'Charlamovsky', 'Gravenstein', 'Transparente Blanche', and 'Wealthy'. Analyses of molecular variance (AMOVA) detected a significant genetic differentiation among the clusters $\left(f_{\mathrm{CT}}=0.077 ; P<0.01\right)$. The results of the Bayesian analyses do not indicate a strong differentiation between the foreign and the Norwegian apple accessions, however, they do suggest that climate adaptation has had a significant influence on the genetic structure of the preserved germplasm. Overall, apple accessions currently maintained ex situ in Norway represent a diverse germplasm which could be very valuable in future breeding programs, especially for the Scandinavian climate.
\end{abstract}

Modernization of fruit production in Norway in the last few decades has led to the clearing of old orchards, containing traditional cultivars, to make room for highdensity orchards, planted with modern international cultivars. In order not to lose the traditional fruit germplasm permanently, collecting missions focusing mainly on apple were initiated in the $1980 \mathrm{~s}$ and $1990 \mathrm{~s}$

Received for publication 15 Aug. 2016. Accepted for publication 7 Oct. 2016.

This study was funded by the Norwegian Genetic Resource Centre (NGRC) and the Norwegian government through HERD (Program for Higher Education, Research and Development) project "Evaluation of fruit genetic resources in Bosnia-Herzegovina with the aim of sustainable, commercial utilization" ref. no. 332160 UE.

${ }^{1}$ Corresponding author. E-mail: mekjell.meland@ nibio.no. data have been collected for most of accessions, to efficiently manage the conserved apple germplasm in Norway, a more detailed and objective characterization is needed. DNA markers are much more efficient, compared with traditional morphological (e.g., pomological) characterizations, in revealing mislabeled plant accession (Nybom and Weising, 2010). Microsatellite markers, also known as simple sequence repeats (SSRs), have shown great promise as a tool for managing Malus ex situ germplasm collections as well as for collection and preservation strategies of these genetic resources (Hokansson et al., 1998). Characterizing accessions maintained in ex situ apple collections, using microsatellite markers, has so far been performed in a number of countries such as Sweden, Finland, Bosnia and Herzegovina, Italy, United States, France, Spain, Holland, and most recently on a Pan-European level (Garkava-Gustavsson et al., 2008, 2013; Gaši et al., 2010, 2013b; Hokanson et al., 2001; Lassois et al., 2016; Liang et al., 2015; Pereira-Lorenzo et al., 2007; Urrestarazu et al., 2012; van Treuren et al., 2010; Urrestarazu et al., 2016). Although the number of examined apple accessions and used SSRs has varied greatly among the mentioned studies, the obtained results have helped increase the efficiency in management of the analyzed collections. The variation in the number of analyzed microsatellite loci has ranged from 8 in early studies (Hokanson et al., 2001) to 24 SSR loci in most recent studies (Lassois et al., 2016), with a notable exception of a study on Finish and Swedish national collections, which relied on the data from eight SSR loci (Garkava-Gustavsson et al., 2013). Although the use of a higher number of SSRs increases the reliability of biostatistical analyses, Gross et al. (2012) have reported that less than 10 SSR loci were sufficient to determine potential duplicates among 1910 accessions in the U.S. Department of Agriculture Malus collection and likely from other large collections of Malus as well. Considering that molecular markers are employed to increase the financial sustainability of the conservation process (by identifying redundancies), the high cost of using an ever larger set of markers, in the analyses of big collections, is not always justified. Aside from accurately fingerprinting the collected accessions, SSR data can be used to investigate the underlying genetic structure and thus gain a much better insight into the examined germplasm. Although the use of a high number of SSR loci can identify even low differentiation within a population, Urrestarazu et al. (2015) report that in the strong structure and moderate differentiation situation, a minimum of eight SSRs is completely sufficient when analyzing Pyrus germplasm. Therefore, in this study, eight highly polymorphic SSR markers were selected to identify redundancies within six ex situ apple collections in Norway, as well as to investigate the genetic diversity and structure of the Norwegian apple germplasm.

\section{Material and Methods}

A total of 181 apple accessions (Supplemental Table 1), maintained in six ex situ collections located in western (Ulvik: $60^{\circ} 33^{\prime} \mathrm{N} 6^{\circ} 55^{\prime} \mathrm{E}$ and Njøs: $61^{\circ} 10^{\prime} \mathrm{N} 6^{\circ} 51^{\prime} \mathrm{E}$ ) 
Table 1. Linkage group, number of detected alleles, effective number of alleles, number of rare alleles (frequency $<0.05$ ), allele size range, gene diversity (Nei, 1978), and probability of identity calculated for 158 apple accessions with unique SSR profile, maintained in six ex situ collections located in western and southeastern Norway.

\begin{tabular}{|c|c|c|c|c|c|c|c|}
\hline Locus code & Linkage group no. & No. of alleles & Effective no. of alleles & No. of rare alleles & Size range (bp) & Gene diversity & Probability of identity \\
\hline$\overline{\mathrm{CH}} 02 \mathrm{C} 02 \mathrm{~b}$ & 4 & 4 & 1.93 & 2 & $97 / 113$ & 0.48 & 0.371 \\
\hline $\mathrm{CH} 04 \mathrm{E} 02$ & 4 & 10 & 4.72 & 5 & $138 / 166$ & 0.79 & 0.075 \\
\hline CH02D08 & 11 & 15 & 4.49 & 10 & $203 / 254$ & 0.78 & 0.078 \\
\hline $\mathrm{CH} 01 \mathrm{H} 01$ & 17 & 11 & 5.66 & 5 & $105 / 141$ & 0.82 & 0.049 \\
\hline $\mathrm{CH} 01 \mathrm{H} 02$ & 9 & 14 & 4.80 & 9 & $227 / 257$ & 0.79 & 0.076 \\
\hline $\mathrm{CH} 01 \mathrm{H} 10$ & 8 & 10 & 3.31 & 5 & $85 / 119$ & 0.70 & 0.125 \\
\hline CH05E03 & 2 & 20 & 4.98 & 16 & $153 / 198$ & 0.80 & 0.068 \\
\hline CH05E04 & 16 & 11 & 6.36 & 4 & $150 / 176$ & 0.84 & 0.048 \\
\hline Average & & 11.9 & 4.53 & & & 0.75 & $3.310^{-9}$ \\
\hline
\end{tabular}

and southeastern (As: $59^{\circ} 40^{\prime} \mathrm{N} 10^{\circ} 46^{\prime} \mathrm{E}$, Dømmesmoen: $58^{\circ} 21^{\prime} \mathrm{N} 8^{\circ} 34^{\prime} \mathrm{E}$, Landvik: $58^{\circ} 20^{\prime} \mathrm{N} 8^{\circ} 31^{\prime} \mathrm{E}$, and Lier: $59^{\circ} 47^{\prime} \mathrm{N}$ $\left.10^{\circ} 15^{\prime} \mathrm{E}\right)$ Norway were sampled for this study, along with 13 international, reference cultivars (Pink Lady, Topaz, Fuji Nagafu, Golden Reinders, Gala Galaxy, Pinova, Pilot, Jonagold, Piros, Braeburn, Melrose, Elstar, and Granny Smith) sampled from an ex situ collection in Bosnia and Herzegovina. Among the sampled accessions, most are considered traditional Norwegian cultivars, whereas some represent foreign cultivars with a longer or shorter tradition of cultivation in Norway. All accessions were genotyped using a set of eight SSR markers, previously used by Gaši et al. (2010, 2013b, 2013a) on traditional apple accessions from Bosnia and Herzegovina.

SSR analyses. Tissue samples for DNA analyses were collected in the autumn of 2014 and 2015, from a single tree for each accession. Genomic DNA was isolated from 70 to $80 \mathrm{mg}$ of leaf powder using the CTAB method (Doyle and Doyle, 1987). Eight primer pairs $(\mathrm{CH} 02 \mathrm{C} 02 \mathrm{~b}, \mathrm{CH} 04 \mathrm{E} 02$, CH02D08, CH01H01, CH01H02, CH01H10, CH05E03, and CH05E04), used for SSR amplifications have previously been published by Gianfranceschi et al. (1998) and Liebhard et al. (2002). None of the analyzed microsatellite markers were multilocus. Polymerase chain reaction (PCR) amplification of SSR sequences was performed in a Veriti TM Thermal Cycler (Applied Biosystems, Foster City, CA) using fluorescently labeled primers. All PCR amplifications were performed as described in Gianfranceschi et al. (1998). PCR product $(1 \mu \mathrm{L})$ was added to a master mix containing $9 \mu \mathrm{L}$ of deionized formamide and $0.5 \mu \mathrm{L}$ GeneScan-350 Rox size-standard (Applied Biosystems). Samples were heated at $95{ }^{\circ} \mathrm{C}$ for $5 \mathrm{~min}$ and immediately cooled down on ice. The detection of SSR products was conducted on ABI 310 automated sequencer (Applied Biosystems). SSR profiles were scored using GeneMapper Software ID v3.2 (Applied Biosystems).

Biostatistical analyses. Population genetics software SPAGeDI 1.3 (Hardy and Vekemans, 2002) was used to calculate allele frequencies, the number of rare alleles per locus (alleles with frequency $<0.05$ ), effective number of alleles, and gene diversity (Nei, 1978). The probability of identity, as defined by Waits et al. (2001) was calculated using GenAlEx ver. 6.5 (Peakall and Smouse, 2006). To examine the genetic structure and differentiation within the Norwegian apple germplasm, we used the Bayesian modelbased cluster procedure within Structure version 2.2.3 (Pritchard et al., 2000). We computed $K$ (unknown) reconstructed panmictic populations (RPPs) of individuals testing $K$ (log-likelihood) $=1-10$ for all accessions assuming that sampled cultivars were from unknown origin. Methodology described by Evanno et al. (2005) was used to estimate the most probable $K$ value for the analyzed data. This was done through Structure harvester ver. 0.6. application (Earl and vonHoldt, 2011). Assignment of a cultivar in an RPP was provided by the probability of membership $q I$ chosen at $80 \%$ according to similar studies in apple (Gaši et al., 2013b; Urrestarazu et al., 2012). In addition, AMOVA (Excoffier et al., 1992) based on the stepwise mutation model, was calculated between the identified RRPs using GenoType software with 1000 permutations. The GenoType program is part of the GenoType/GenoDive package (Meirmans and Van Tienderen, 2004). A multivariate analysis, factorial correspondence analysis (FCA) based on allele frequencies was performed using Genetix 4.02 (Belkhir et al., 2001), which meant excluding all triploid genotypes.

\section{Results and Discussion}

SSR polymorphism. Eight primer pairs amplified 95 distinct alleles in this study, or on average 11.9 alleles per locus (Table 1). This is higher than the values published from similar studies on cultivated apple germplasm in Denmark (9.8) (Larsen et al., 2006), Sweden (10.3) (Garkava-Gustavsson et al., 2008), and Finland (8.8) (Garkava-Gustavsson et al., 2013). It is important to note that all except one (Garkava-Gustavsson et al., 2013) of the mentioned studies employed more than eight SSR markers. Slightly higher values have been reported on Spanish germplasm by Pereira-Lorenzo et al. (2007) (12.3). Much higher average number of alleles per SSR loci have been reported by van Treuren et al. (2010) (18.5), Urrestarazu et al. (2012) (16.7), Liang et al. (2015) (16.8), and Lassois et al. (2016) (19.5). However, the number of accessions included in the four mentioned studies ranged from 400 to above 2000 . The average effective number of alleles in this
Table 2. List of synonym apple accessions found in six Norwegian ex situ collections using eight SSR primer pairs.

'Cellini' (Lier), 'Hampus' (Lier), and 'Husmor' (Lier)

'Gravenstein hollandsk' (Ulvik) and 'Hollandsk Gravenstein' (Dømmesmoen)

'Løkeple' (Njøs) and 'Silke-eple' (Njøs)

'Tommos' (As) and 'Keiserkrone' (Njøs)

'Simenraud' (Lier) and 'Melba raud' (Njøs)

'Lærdalseple' (Njøs) and 'Lavoll' (Njøs)

'Laxtons Exquisite'(Ulvik), 'Laxtons Superb'

(Lier), and 'Lord Lambourne' (Ulvik)

'Prins' (Njøs) and 'Prins Kronprins' (Njøs)

'Ribston' (Lier) and 'Ribston Lagerod'

(Dømmesmoen)

'Ekely' (Njøs) and 'Oster' (Njøs)

'Haustkavill' (Lier) and 'Kjerrigholm' (Lier)

'Langballe' (Njøs) and 'Kavill' (Ulvik)

study (4.53) was lower, but comparable to the values published on Finnish (4.66) (GarkavaGustavsson et al., 2013) and Swedish (4.93) (Garkava-Gustavsson et al., 2008) apple germplasm. Even higher values have been reported by Urrestarazu et al. (2012) (6.69), Liang et al. (2015) (5.64), and Lassois et al. (2016) (6.2). The substantial difference between the average allele number and the average effective allele number in this study is probably due to a high presence of rare alleles (56 alleles or $59 \%$ of all detected alleles). High percentage of rare alleles indicates a presence of a considerable genetic diversity among the analyzed apple accessions, previously unused in breeding. The calculated gene diversity (0.75) (Table 1) was comparable to the value reported for Swedish apple germplasm (0.74) (GarkavaGustavsson et al., 2008) and identical to the values published for the Finnish apple germplasm (Garkava-Gustavsson et al., 2013). Somewhat higher values for gene diversity have been reported by Urrestarazu et al. (2012) (0.82), Liang et al. (2015) (0.83), and Lassois et al. (2016) (0.82), however, on much larger set of samples. The highest value for probability of identity was calculated for $\mathrm{CH} 02 \mathrm{C} 02 \mathrm{~b}(0.371)$, whereas the lowest for CH05E04 (0.048) (Table 1). Since the overall probability of identity was quite low $\left(3.3 \times 10^{-9}\right)$, the risk that two random accessions were erroneously assigned as identical is very unlikely.

Detection of more than two different alleles per locus, indicating a triploid state, 
was observed for $22 \%$ or $12 \%$ of accessions from Norway (Supplemental Table 1). The percentage of genotypes with a third allele on one or more loci was comparable to the values reported by Garkava-Gustavsson et al. (2008) (10\%) for the Swedish apple germplasm, but lower than $19 \%$ and $21 \%$ reported for the French (Lassois et al., 2016) and the Dutch (van Treuren et al., 2010) apple collections, respectively. Even higher percentage of these genotypes has been reported for apple germplasm maintained ex situ in northwestern (Pereira-Lorenzo et al., 2007)

Table 3. List of presumable mutants found in six Norwegian ex situ, which display identical genetic profiles obtained using eight SSR primer pairs.

'Ingrid Marie' (Lier) and 'Ingrid Marie raud' (̊̊s)

'Prins' (Njøs) and 'Prins raud' (Ås)

'James Grieve' (Lier) and 'James Grieve, raud' (Njøs)

'Sävstaholm' (Lier) and 'Sävstaholm raud' (Ulvik) 'Stor Torstein' (Njøs) and 'Torstein raud' (Njøs)
(28\%) and northeastern Spain (Urrestarazu et al., 2012) (24\%), as well as for Bosnia and Herzegovina (Gaši et al., 2010, 2013b) $(27 \%)$, which might indicate a higher presence of triploids among southern European germplasm compared with the Nordic ones.

Genetic identification. Overall, 14 cases of synonyms or possible mislabeling were detected (Table 2), of which eight were among accessions within individual collections, and the rest between accessions maintained at different sites. Several cases of homonyms or misleading names were also detected within the Norwegian apple collections 'Astrakan gyllenkroks', 'Astrakan kvit', and 'Astrakan raud' from Lieralthough all three accessions have 'Astrakan' in their name, they are not genetically identical or even closely related. In addition, 'Fuhr' and 'Fuhr raud' from Njøs-the names suggest that 'Fuhr raud' is a red mutant of Fuhr cultivar. Indeed, they are closely related but not genetically similar enough to be considered clones (differences on three SSR loci). However, these two accessions display differences in only one allele in each of the three loci, possibly indicating that 'Fuhr red' is an offspring of 'Fuhr'. Out of four 'Gravenstein' apple accessions analyzed, 'Gravenstein' accession from Ulvik, with the attribute "hollandsk" (Dutch), is identical to "Hollandsk Gravenstein' from Dømmesmoen. Meanwhile, 'Gravenstein fusa' from Njøs is not closely related to any of the other 'Gravenstein' accessions. Two 'Laupsa-eple grønt' accessions from Ulvik are completely unrelated genotypes; one of the 'Lord Lambourne' accessions from Dømmesmoen is not closely related to the other two analyzed 'Lord Lambourne' accessions (from Dømmesmoen and Ulvik); 'Rosenstrip' and 'Rosenstrip Sogn', both from $\mathrm{Njøs}$, are in fact completely different genotypes, whereas 'Vinterrosenstrips' (Ulvik), was not identical or closely related to any of the other genotypes containing the name "Rosenstrip." "Torstein gul' from Ulvik is genetically completely different from 'Stor Torstein' and 'Torstein raud', both from Njøs.

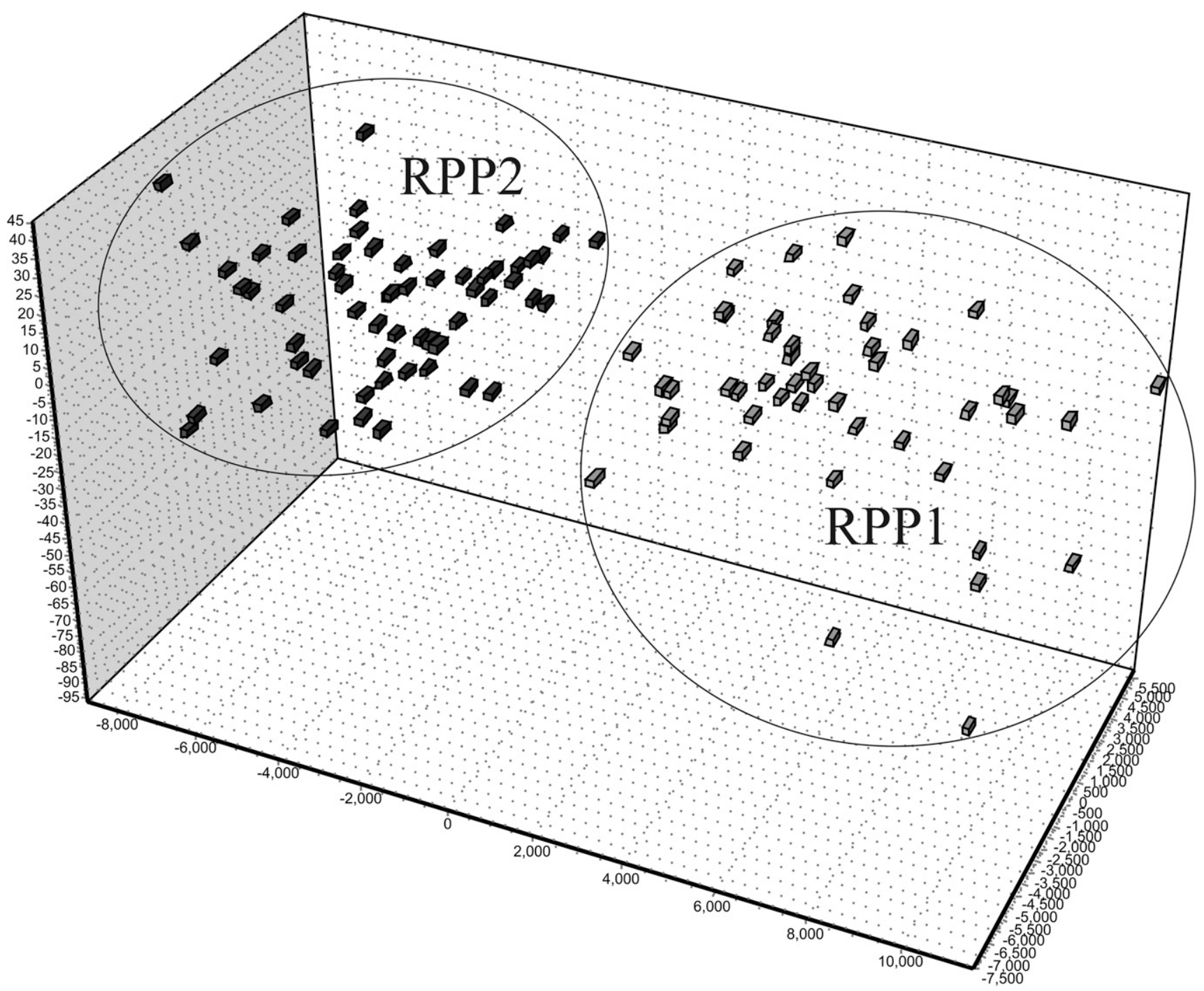

Fig. 1. Multivariate analysis (factorial correspondence analysis) of simple sequence repeat data for two defined reconstructed panmictic populations (RPPs) (only diploid genotypes with likelihood of membership to individual RPP above $80 \%$ ). 
The analyses of eight SSR loci revealed differences in one allele among the genetic profiles of 'Aroma' and 'Aroma raud' ('Aroma red'), as well as between 'Haugmann' (Ulvik) and 'Haugmann' (Njøs), indicating clonal polymorphism. On the other hand, several pairs of accessions, which are considered to be mutants, could not be differentiated using these SSR markers (Table 3).

Duplicates in ex situ collections (accessions carrying the same name and which have the same SSR profile) were few: 'Akerø hassel' (Lier), 'Åkerø', and 'Åkerø hassel' (both from Ulvik) all have the same names and also have an identical genetic profile; 'Lord Lambourne' from Ulvik and one of the accessions registered as 'Lord Lambourne' from Dømmesmoen have an identical genetic profile; two 'Silke-eple', from Njøs and Lier collection, respectively, have identical names and have an identical genetic profile. It is important to note that properly identified duplicate accessions, maintained in more than one collection, can be useful as reference genotypes, as well as safety backups.

Out of 181 analyzed accessions, from six ex situ collections located in western and south-eastern Norway, 158 displayed a unique SSR profile. The identified percentage of redundancies $(13 \%)$, in this study, is lower than what has been reported for apple collections in the Netherlands (van Treuren et al., 2010) (32\%), Spain (Urrestarazu et al., 2012) (47\%), Italy (Liang et al., 2015) (34\%) and France (34\%) (Lassois et al., 2016), but equal to the values reported by Gaši et al. (2013b) (13\%). Although the redundancy does not appear to be a major issue within the analyzed Norwegian collections, the use of SSR markers has identified all the mislabeled accessions, which should contribute to a more efficient management of the collected germplasm. The process of renaming the mislabeled accessions will be aided by available passport data. Also, a morphological reevaluation of suspected synonyms needs to be conducted before removing any of the accessions from the collections.

Genetic structure. Bayesian analyses of 194 accessions (181 accessions from Norwegian ex situ collections and 13 international, reference cultivars) was conducted using Structure. Subsequent $\Delta K$ analyses (Evanno et al., 2005) revealed a maximum value for $K=2$, with no additional substructuring within the two identified RPPs. Overall, 62 accessions clustered in RPP1 and 76 in RPP2, whereas 56 accessions were admixed (did not adhere to any of the two RPPs with the probability of membership above $80 \%$ ) (Supplemental Table 1). RPP1 consisted mainly of traditional Scandinavian cultivars, but notably included some very winter-hardy cultivars such as Charlamovsky, Gravenstein, Transparente Blanche, and Wealthy.

Twelve of the 13 international, reference cultivars clustered inside RPP2. Numerous old apple cultivars introduced to Norway from western Europe and North America ('Beauty of Bath', 'Belle de Boskoop', 'Cox's Orange', 'Jacques Lebel', 'James
Grieve', 'Laxtons Superb', 'Lord Lambourne', 'Summerred', 'Wagener', 'Worcester Pearmain', etc.) also grouped within the same RPP. Foreign apple germplasm had a significant presence among the admixed accessions ('Bramleys seedling', 'Dunelow seedling', 'Early McIntosh', 'Early Red Bird', 'Geneva Early', etc.), including one of the international, reference cultivars (Fuji Nagafu). The genetic differentiation between the two identified RPPs was examined using AMOVA. AMOVA detected that most of the variance was retained within the RRPs $(92.3 \%)$, whereas $7.7 \%$ of the total diversity was attributed to the differences among the analyzed groups of accessions. The obtained values for AMOVA were significant $\left(f_{\mathrm{CT}}=\right.$ $0.077 ; P<0.01)$. To get a clearer picture of the genetic relationships between the analyzed RPPs, a FCA was performed. The separation between the two clusters (Fig. 1) was evident and thus the FCA confirmed results obtained by AMOVA.

No correlation was found between the geographical location of the individual accession and their RPP distribution. However, large presence of foreign apple cultivars introduced from southern countries within RPP2, together with a dominant occurrence of traditional Scandinavian and very winterhardy cultivars within RPP1, indicates that climate adaptation may have contributed significantly to the genetic structure of the analyzed germplasm. The effect of climate adaptation on genetic structure of apple germplasm was previously hypothesized by Garkava-Gustavsson et al. (2013) in a study on Finish and Swedish national apple collections.

\section{Conclusion}

Using eight polymorphic SSR markers, we managed to identify a number of mislabeled accessions, as well as duplicates, among apple accessions conserved within six ex situ collections located in Norway, which should contribute to a more efficient management of the collected germplasm. It is necessary to rename the mislabeled accessions to avoid future confusion. Available passport data should help in this process.

The results of the Bayesian analyses do not indicate a strong differentiation between the foreign and the Norwegian apple accessions; however, there is some evidence that the climate adaptation has influenced the genetic structure of the examined germplasm. On the basis of the low occurrence of redundancies and calculated diversity parameters, apple accessions currently maintained ex situ in Norway represent a diverse germplasm which could be very valuable in future breeding programs, especially for the Scandinavian climate.

\section{Literature Cited}

Belkhir, K., P. Borsa, L. Chikhi, N. Raufast, and F. Bonhomme. 2001. GENETIX 4.02, logiciel sous Windows TM pour la génétique des populations. Laboratoire Génome, Populations,
Interactions, CNRS UMR 5000, Université de Montpellier II, Montpellier, France.

Doyle, J.J. and J.L. Doyle. 1987. A rapid DNA isolation procedure for small quantities of fresh leaf tissue. Phytochem. Bull. 19:11-15.

Earl, D.A. and B.M. Von Holdt. 2011. Structure harvester: A Website and program for visualizing STRUCTURE output and implementing the Evanno method. Conserv. Genet. Resour. 4:359-361.

Evanno, G., S. Regnaut, and J. Goudet. 2005 Detecting the number of clusters of individuals using the software STRUCTURE: A simulation study. Mol. Ecol. 14:2611-2620.

Excoffier, L., P.E. Smouse, and J.M. Quattro. 1992. Analysis of molecular variance inferred from metric distances among DNA haplotypes: Application to human mitochondrial DNA restriction data. Genetics 131:479-491.

Garkava-Gustavsson, L., K. Kolodinska-Brantestam, J. Sehic, and H. Nybom. 2008. Molecular characterization of indigenous Swedish apple cultivars based on SSR and $S$-allele analysis. Hereditas 145:99-112.

Garkava-Gustavsson, L., C. Mujaju, J. Sehic, A. Zborowska, G.M. Backes, T. Hietaranta, and K. Antonius. 2013. Genetic diversity in Swedish and Finnish heirloom apple cultivars revealed with SSR markers. Sci. Hort. 162:43-48.

Gaši, F., S. Šimon, N. Pojskić, M. Kurtović, and I. Pejić. 2010. Genetic assessment of apple germplasm in Bosnia and Herzegovina using microsatellite and morphologic markers. Sci. Hort. 126(2):164-171.

Gasi, F., S. Simon, N. Pojskic, M. Kurtovic, I. Pejic, M. Meland, and C. Kaiser. 2013a. Evaluation of apple (Malus $\times$ domestica) genetic resources in Bosnia and Herzegovina using microsatellite markers. HortScience 48:13-21.

Gaši, F., M. Žulj Mihaljević, S. Šimon, J. Grahić, N. Pojskić, M. Kurtović, D. Nikolić, and I. Pejić. 2013b. Genetic structure of apple accessions maintained ex situ in Bosnia and Herzegovina examined by microsatellite markers. Genetika 45(2):467-478.

Gianfranceschi, L., N. Seglia, R. Tarchini, M. Komjanc, and C. Gessler. 1998. Simple sequence repeats for the genetic analyses of apple. Theor. Appl. Genet. 96:1069-1079.

Gross, B.L., G.M. Volk, C.M. Richards, P.L. Forsline, G. Fazio, and C.T. Chao. 2012. Identification of 'duplicate' accessions within the USDA-ARS National Plant Germplasm System Malus collection. J. Amer. Soc. Hort. Sci. 137:333-342.

Hardy, O.J. and X. Vekemans. 2002. A versatile computer program to analyse spatial genetic structure at the individual or population level. Mol. Ecol. Notes 2:618-620.

Hjeltnes, S.H. 2008. Gamle sorter av frukt og bær. <http://www.skogoglandskap.no/filearchive/ norske_klonarkiv_i_frukt.pdf $\$$.

Hokanson, S.C., W.F. Lamboy, A.K. SzewcMcFadden, and J.R. McFerson. 2001. Microsatellite (SSR) variation in a collection of Malus (apple) species and hybrids. Euphytica 118:281-294.

Hokansson, S.C., A.K. Szewc-McFadden, W.F. Lamboy, and J.R. McFerson. 1998. Microsatellite (SSR) markers reveal genetic identities, genetic diversity and relationship in a Malus $\times$ domestica Borkh. core subset collection. Theor. Appl. Genet. 97:671-683.

Larsen, A.S., C.B. Asmussen, E. Coart, D.C. Olrik, and E.D. Kjær. 2006. Hybridization and genetic variation in Danish populations of European crab apple (Malus sylvestris). Tree Genet. Genomes 2:86-97. 
Lassois, L., C. Denancé, E. Ravon, A. Guyader, R. Guisnel, L. Hibrand-Saint-Oyant, C. Poncet, P. Lasserre-Zuber, L. Feugey, and C. Durel. 2016. Genetic diversity, population structure, parentage analysis, and construction of core collections in the French apple germplasm based on SSR markers. Plant Mol. Biol. Rpt. 34(4):827-844.

Liang, W., L. Dondini, P. De Franceschi, R. Paris, S. Sansavini, and S. Tartarini. 2015. Genetic diversity, population structure and construction of a core collection of apple cultivars from Italian germplasm. Plant Mol. Biol. Rpt. 33 (3):458-473.

Liebhard, R., L. Gianfranceschi, B. Koller, C.D. Ryder, R. Tarchini, E. Van De Weg, and C. Gessler. 2002. Development and characterization of 140 new microsatellites in apple (Malus $\times$ domestica Borkh.). Mol. Breed. 10:217-241.

Meirmans, P. and P. Van Tienderen. 2004. Genotype and genodive: Two programs for the analysis of genetic diversity of asexual organisms. Mol. Ecol. Notes 4(4):792-794.

Nei, M. 1978. Estimation of average heterozygosity and genetic distance from a small number of individuals. Genetics 89:583-590.
Nybom, H. and K. Weising. 2010. DNA-based identification of clonally propagated cultivars, p. 221-295. In: J. Janick (ed.). Plant breeding reviews. Vol. 34. John Wiley \& Sons, Inc.

Peakall, R.O.D. and P.E. Smouse. 2006. GENALEX 6: Genetic analysis in Excel. Population genetic software for teaching and research. Mol. Ecol. Notes 6:288-295.

Pereira-Lorenzo, S., A.M. Ramos-Cabrer, and M.B. Diaz-Hernandez. 2007. Evaluation of genetic identity and variation of local apple cultivars (Malus $\times$ domestica Borkh.) from Spain using microsatellite markers. Genet. Resources Crop Evol. 54:405-429.

Pritchard, J.K., M. Stephens, and P. Donnelly. 2000. Inference of population structure using multilocus genotype data. Genetics 155:945-959.

van Treuren, R., H. Kemp, G. Ernsting, B. Jongejans, H. Houtman, and L. Visser. 2010. Microsatellite genotyping of apple (Malus $\times$ domestica Borkh.) genetic resources in the Netherlands: Application in collection management and variety identification. Genet. Resources Crop Evol. 57:853-865.

Urrestarazu, J., C. Miranda, L.G. Santesteban, and J.B. Royo. 2012. Genetic diversity and structure of local apple cultivars from northeastern Spain assessed by microsatellite markers. Tree Genet. Genomes 8(6):11631180.

Urrestarazu, J., J.B. Royo, L.G. Santesteban, and C. Miranda. 2015. Evaluating the influence of the microsatellite marker set on the genetic structure inferred in Pyrus communis L. PLoS One 10(9):E0138417.

Urrestarazu, J., C. Denancé, E. Ravon, A. Guyader, R. Guisnel, L. Feugey, C. Poncet, M. Lateur, P. Houben, M. Ordidge, F. FernandezFernandez, K.M. Evans, F. Paprstein, J. Sedlak, H. Nybom, L. Garkava-Gustavsson, C. Miranda, J. Gassmann, M. Kellerhals, I. Suprun, A.V. Pikunova, N.G. Krasova, E. Torutaeva, L. Dondini, S. Tartarini, F. Laurens, and C.E. Durel. 2016. Analysis of the genetic diversity and structure across a wide range of germplasm reveals prominent gene flow in apple at the European level. BMC Plant Biol. 16:130.

Waits, L.P., G. Luikart, and P. Taberlet. 2001. Estimating the probability of identity among genotypes in natural populations: Cautions and guidelines. Mol. Ecol. 10:249-256. 


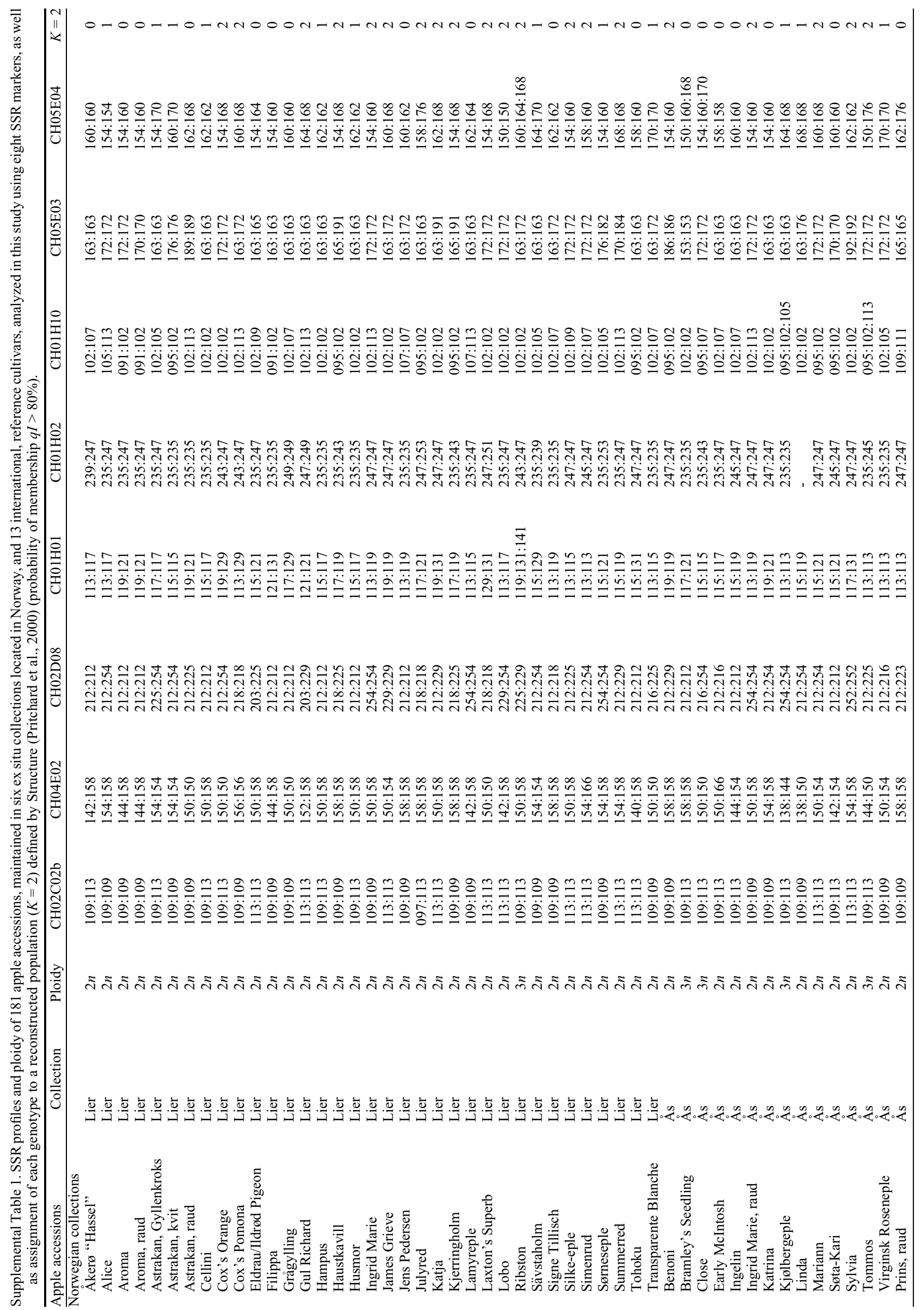

HortScience Vol. 51(12) December 2016 
0
0

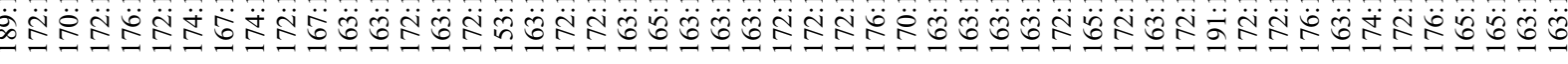
$\stackrel{1}{2}$
$\stackrel{2}{9}$
$\stackrel{3}{3}$
응응

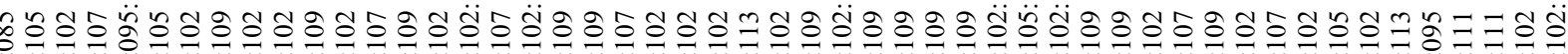

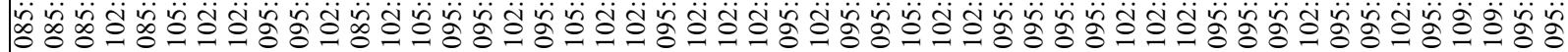

\section{$\overline{3}$}

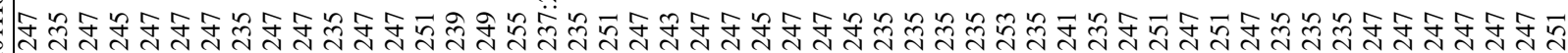

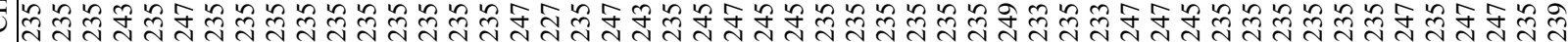

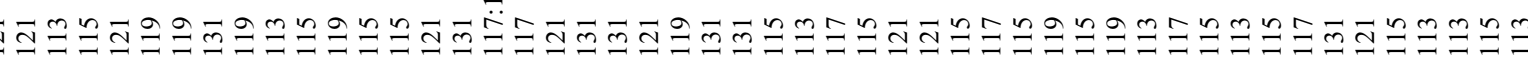

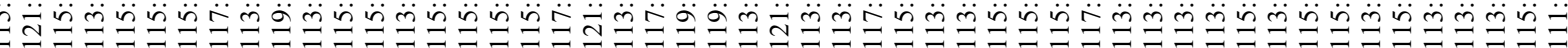

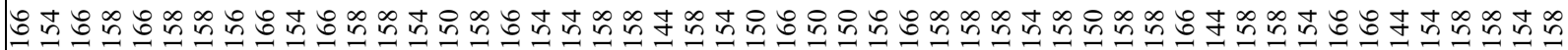

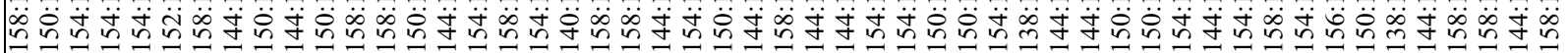

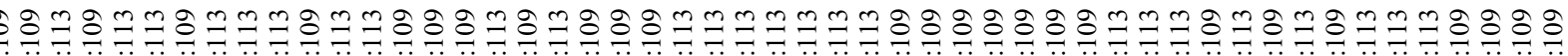

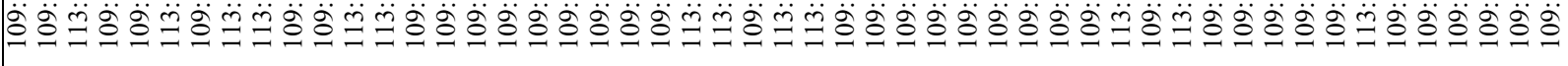

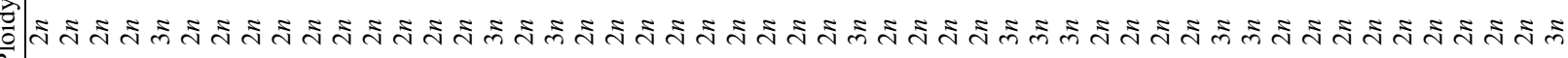

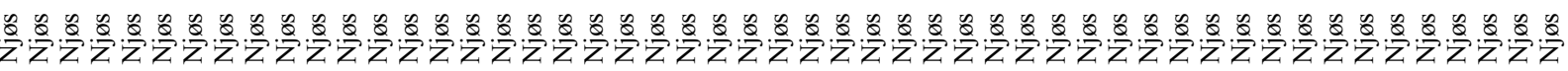

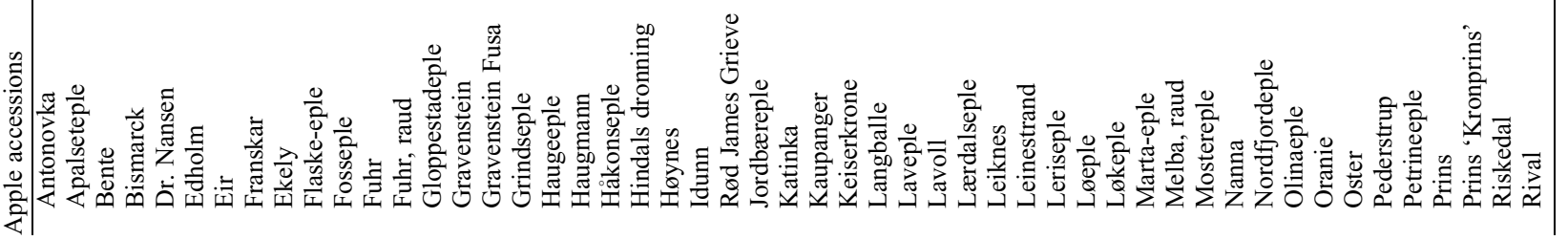




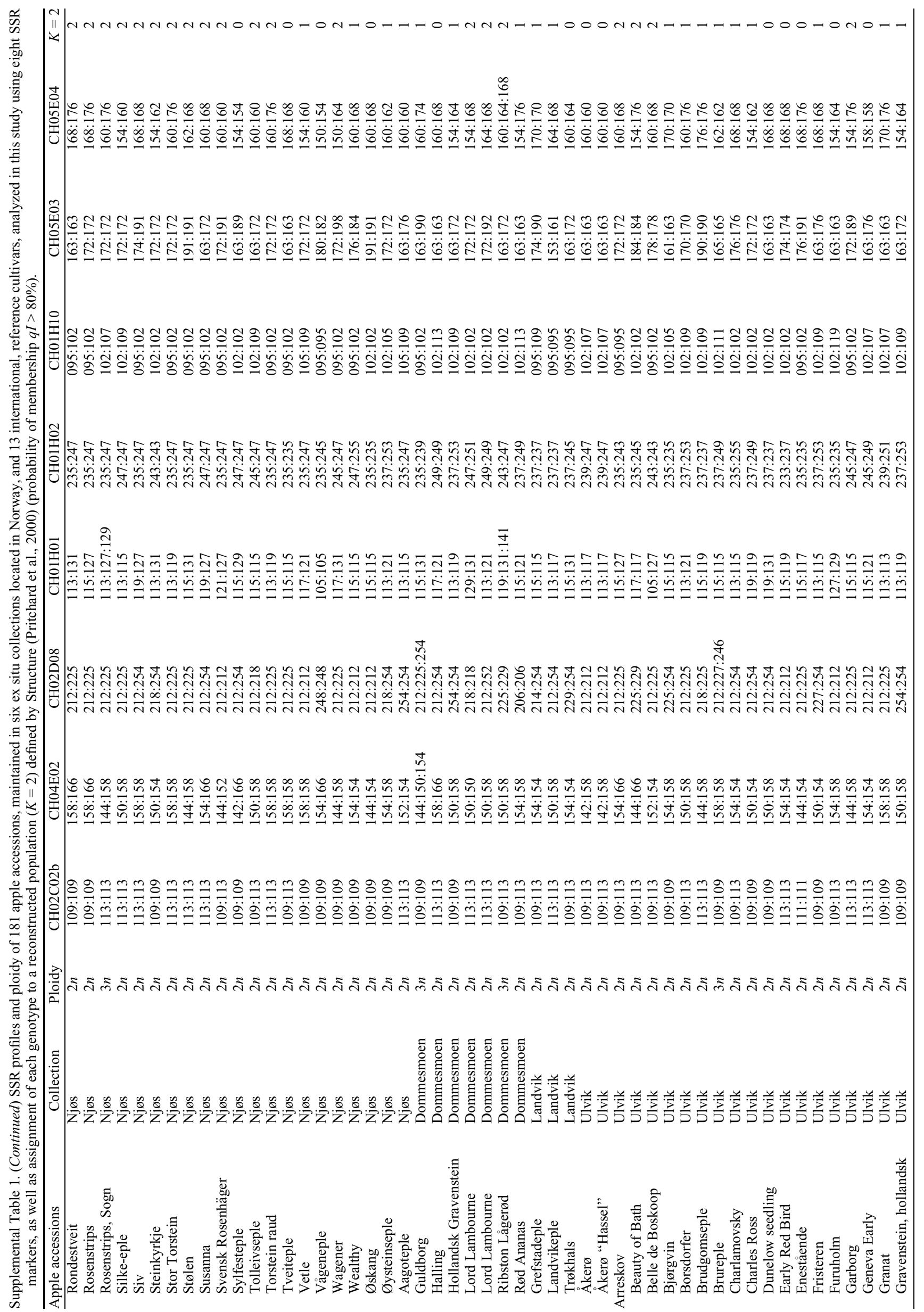

HortScience Vol. 51(12) December 2016 


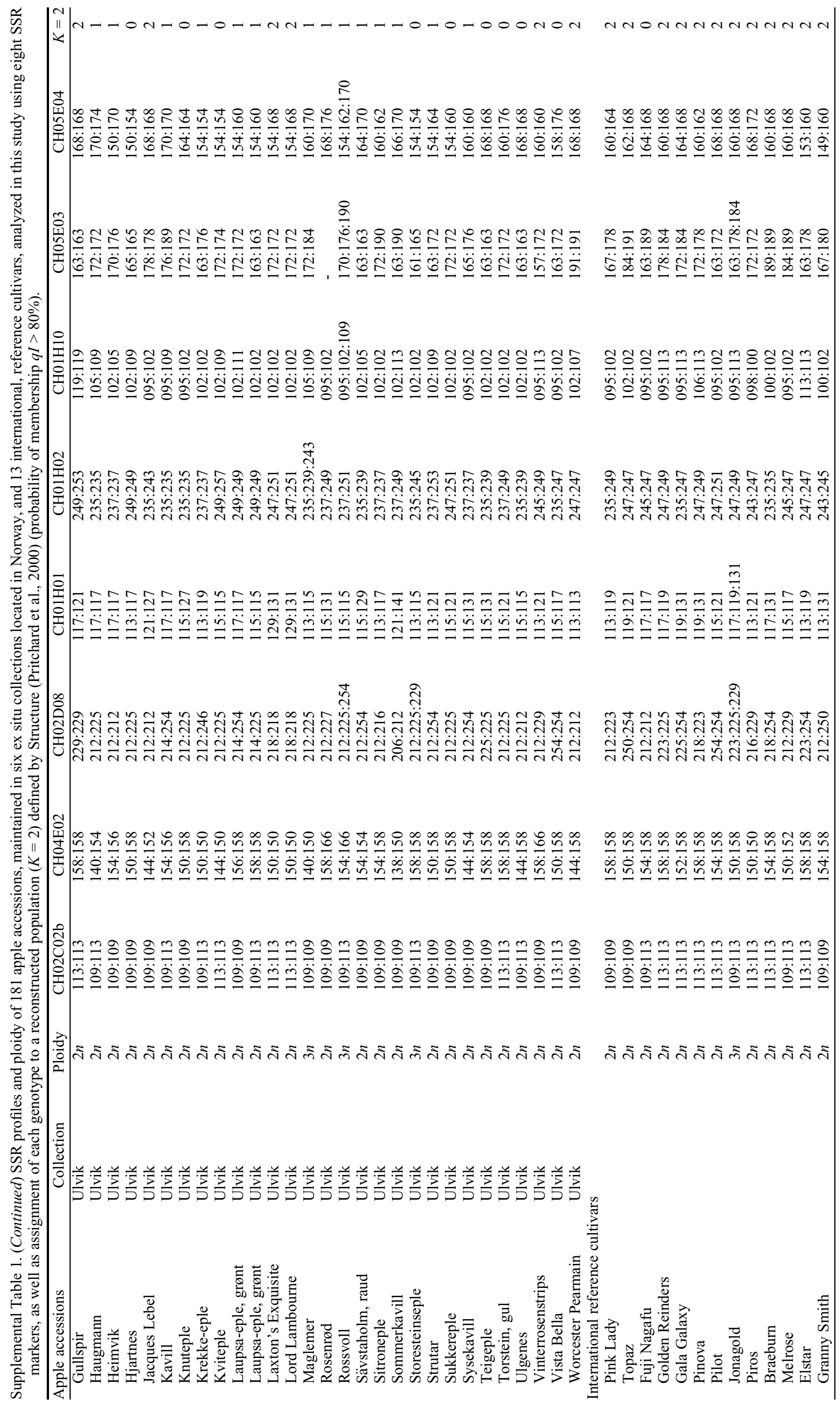

